\title{
EXPOSURE AND RISK ASSESSMENT CONNECTED TO THE HEALTH AND SAFETY OF WORKERS IN THE PRODUCTION OF ELECTRICITY
}

\author{
M. Israel ${ }^{1,2^{*}}$, P. Ivanova ${ }^{2}$, Ts. Shalamanova ${ }^{2}$, M. Ivanova $^{2}$, V. Zaryabova ${ }^{2}$ \\ ${ }^{1}$ Medical University - Pleven, Bulgaria \\ ${ }^{2}$ National Center of Public Health and Analyses, Sofia, Bulgaria
}

\begin{abstract}
The aim of the study is to perform exposure and risk assessment of electromagnetic fields (EMF) at workplaces connected with electricity production according to the requirements of Directive 2013/35/EU. The study covers the following sets of workplaces: (1) Workplaces in power distribution systems (indoor and outdoor distribution systems); (2) Workplaces with metalworking machines: lathes, mills, electric welding. Measurements are made using a frequency non-selective method, based on: "Non-binding guide to good practice for implementing Directive 2013/35/EU Electromagnetic Fields Vol. 1 - Practical guide”. Exposure and risk assessment have been performed by comparing the measured values with action values (ALs) and the exposure limit values (ELVs) according to the requirements of Directive 2013/35/EU, as well as with the reference values adopted by the Council Recommendation 1999/519/EC for persons at "specific risk". The results of the exposure and risk assessment show the following: Electric field strength for the power frequency field $(5 \mathrm{O} \mathrm{Hz})$ does not exceed the high ALs for non-thermal effects; low ALs are not exceeded except for single points in outdoor high voltage substations. In cases where the low ALs for non-thermal effects are exceeded, the reference levels according to Recommendation 1999/519/EC are also exceeded. There are no measured values of the field strength above the reference levels according to Council Recommendation 1999/519/EC at the remaining workplaces. The results show compliance with the ELVs with respect to the health and sensory effects. Magnetic flux density values of power frequency fields do not exceed the ALs for non-thermal effects. Measured values also show the compliance with the ELVs for health and sensory effects. The magnetic flux densities do not exceed the reference levels according to Council Recommendation 1999/519/EC. From the results obtained, it can be concluded that no risk can be expected for the workers' health from the EMFs exposure except for those defined as persons at a specific risk. For them, appropriate recommendations for the employer have been proposed for health and safety practices at work.
\end{abstract}

Keywords: Action levels, electromagnetic fields, exposure limits, specific risk

\section{INTRODUCTION}

In Bulgaria, the EU Directive 2013/35/EC [2] has been transposed into national legislation by Ordinance RD-07-5 for the minimal requirements for providing health and safety at work at risks by exposure to electromagnetic fields [3, 7] in 2016 and entered into force in 2017.

In connection with the introduction of new assessment requirements, such as exposure limit values (ELVs) and action levels (ALs) for electrical, magnetic and electromagnetic (EMF) with frequencies up to $300 \mathrm{GHz}$, as well as the necessity to assess new physical parameters, a need arose to change approaches regarding the exposure and risk assessment of EMFs in for different professional groups. Some of these parameters are not measurable, and calculations and modeling are very important activities in cases where the values are close to or above the corresponding ALs.
Regarding this, a team from the National Center of Public Health and Analyses (NCPHA) carried out measurement and exposure and risk assessment of work places in electricity producing sector, according to the requirements of Directive 2013/35/EU.

The expected adverse effects of electrical and magnetic fields with power frequency are: direct effects on the nervous system, analyzers, skin receptors and muscles due to the influence of extremely low frequency range EMF and indirect effects caused by the presence of an object in the electromagnetic field.

\section{AIM OF THE STUDY}

Exposure and risk assessment of EMF on workplaces at workshops in electrical power plants according to requirements of Directive 2013/35/EU [2].

*michelisrael@abv.bg 
M. Israel et al., EMF exposure and risk assessment of electricity workers, RAP Conf. Proc., vol. 5, 2020, 51-54

\section{MATERIALS AND METHODS}

\subsection{Work places}

The study covers the exposure assessment of all jobs related to the work equipment combined into the following groups of work places/occupations depending on the technology:

$>$ Workplaces in electrical distribution systems (internal and external distribution systems);

$>$ Workstations with metalworking machines: lathes, milling machines, electric welding;

$>$ Workplaces in electrolysis.

\subsection{Measurement method}

Measurements are performed by applying a frequency non-selective method using the "Nonbinding guide to good practice for implementing Directive 2013/35/EU, Electromagnetic fields, Volume 1: Practical guide"[4].

\subsection{Measurement parameters}

Electric field strength, $\mathrm{V} / \mathrm{m}$;

Magnetic flux density, $\mu \mathrm{T}$.

\subsection{Measurement equipment}

For measurement purposes, the following equipment was used:

a. Holaday Industries HI 3550, USA

- InAs Hall effect Sensor

- measurement range for static magnetic field: $0.1 \mathrm{mT}$ to $0.3 \mathrm{~T}$

Uncertainty: in the range from $0.1 \mathrm{mT}$ to $0.5 \mathrm{mT}$ $\pm 0.05 \mathrm{mT} ; \pm 10 \%$ in the range from $0.5 \mathrm{mT}$ to $0.3 \mathrm{~T}$.

b. Holaday Industries $\mathrm{HI}_{3} 604$, USA

- anisotropic probe,

- frequency range :20 Hz - $2 \mathrm{kHz}$ for electric field; $20 \mathrm{~Hz}$ to $1 \mathrm{kHz}$ for magnetic field;

Uncertainty: $\pm 20 \%$.

The measurement equipment for the low-frequency range covers the power frequency $(50 \mathrm{~Hz})$ and harmonics, including frequencies up to $1 \mathrm{kHz}$ or $2 \mathrm{kHz}$, to comprise the emission of spark discharges at high voltages. The dynamic range of the measuring instrument has been selected so that an exposure assessment can be made for both workers protection in the presence of EMFs and the general public protection. The purpose of the latter is to assess the possible risk for workers at "specific risk".

The measured values are root mean square (rms) with averaging over 6-minute periods. The presented measurement data are the maximum rms values obtained for the corresponding occupations/workplaces.

Exposure and risk assessment have been performed by comparison of the measured values with the action levels (ALs) and the exposure limit values (ELVs) as required by Directive 2013/35/EC (Ordinance № RD07-5/15.11.2016 г.) [2, 7].

Regarding the risk assessment, we mainly took into account the characteristics of the occupation and work tasks and the specific risk definitions. The limit values adopted by Council Recommendation 1999/519/EC [1] were used as a reference for workers at "specific risk".

This group includes workers carrying active or passive implants, workers carrying medical devices on their bodies, as well as external hormone infusion pumps as well as pregnant workers.

\section{RESULTS AND DISCUSSION}

Measurements have been performed at more than 150 points on workplaces, on walkways and observation areas. The survey results are grouped by occupations/workplaces, technologies and workshops.

As it was expected, the results from measurements in electric workshop/electrical occupations are of greatest interest in terms of exposure to electric and magnetic fields.

Hereafter results for selected occupations/jobs in electrical distribution systems (indoor and outdoor distribution systems) where the highest exposure to EMFs occurs are presented.

Table 1 shows data from the measurement of the electric field strength on selected work places in electrical distribution systems.

Table 1. Electric field strength in electrical distribution system

\begin{tabular}{|c|c|c|c|c|}
\hline $\begin{array}{l}\text { Highest } \\
\text { measured } \\
\text { value }\end{array}$ & $\begin{array}{c}\text { Low } \\
\text { ALs } \\
\text { (for } 50 \\
\text { Hz) }\end{array}$ & $\begin{array}{l}\text { High } \\
\text { ALs } \\
\text { (for 50 } \\
\text { Hz) }\end{array}$ & Risk & \multirow{2}{*}{$\begin{array}{l}\text { Workers } \\
\text { at } \\
\text { specific } \\
\text { risk }\end{array}$} \\
\hline $\begin{array}{l}\mathrm{E}_{\max } \\
\mathrm{V} / \mathrm{m}\end{array}$ & $\begin{array}{c}10000 \\
\mathrm{~V} / \mathrm{m}\end{array}$ & $\begin{array}{l}20000 \\
\mathrm{~V} / \mathrm{m}\end{array}$ & $\begin{array}{l}\text { low } \\
\text { medium } \\
\text { high }\end{array}$ & \\
\hline \multicolumn{5}{|c|}{$\begin{array}{c}\text { Workplace } \\
\text { door distribution system } 6 \mathrm{\kappa V}\end{array}$} \\
\hline 8.03 & - & - & low & - \\
\hline \multicolumn{5}{|c|}{$\begin{array}{l}\text { Workplace on } \\
\text { asformer platform; under rims }\end{array}$} \\
\hline 11970 & $\checkmark$ & - & medium & $\sqrt{ }$ \\
\hline \multicolumn{5}{|c|}{$\begin{array}{c}\text { Workplace } \\
\text { measuring instruments }\end{array}$} \\
\hline 103 & - & - & low & - \\
\hline \multicolumn{5}{|c|}{$\begin{array}{c}\text { Workplace } \\
\text { Transformer own needs } \\
28 \mathrm{~T}-15.76 / 6 \mathrm{KV}\end{array}$} \\
\hline 1280 & - & - & low & - \\
\hline \multicolumn{5}{|c|}{$\begin{array}{c}\text { Workplace } \\
\text { Block Transformer } \\
- \text { 7T, 15.75/400 } \\
\text { Under rims } \\
\end{array}$} \\
\hline 5020 & - & - & medium & $\checkmark$ \\
\hline \multicolumn{5}{|c|}{$\begin{array}{c}\text { Workplace } \\
\text { Block Transformer }-8 \mathrm{~T} \text {, } \\
15 \cdot 75 / 400 \\
\text { Under rims } \\
\end{array}$} \\
\hline 5340 & - & - & medium & $\checkmark$ \\
\hline
\end{tabular}

Note: Reference level - $5000 \mathrm{~V} / \mathrm{m}$

Table 2 shows data from the measurement of the magnetic flux density on selected work places in electrical distribution systems. 
M. Israel et al., EMF exposure and risk assessment of electricity workers, RAP Conf. Proc., vol. 5, 2020, 51-54

Table 2. Magnetic flux density in electrical distribution system

\begin{tabular}{|c|c|c|c|c|}
\hline $\begin{array}{l}\text { Highest } \\
\text { measured } \\
\text { value }\end{array}$ & $\begin{array}{c}\text { Low } \\
\text { ALs } \\
\text { (for 50 } \\
\text { Hz) }\end{array}$ & $\begin{array}{c}\text { High } \\
\text { ALs } \\
\text { (for 50 } \\
\text { Hz) } \\
\end{array}$ & Risk & \multirow{2}{*}{$\begin{array}{l}\text { Workers } \\
\text { at } \\
\text { specific } \\
\text { risk }\end{array}$} \\
\hline $\mathrm{B}_{\max }$ & $\begin{array}{c}1000 \\
\mu \mathrm{T}\end{array}$ & $\begin{array}{l}6000 \\
\mu \mathrm{T}\end{array}$ & $\begin{array}{c}\text { low } \\
\text { medium } \\
\text { high }\end{array}$ & \\
\hline \multicolumn{5}{|c|}{$\begin{array}{l}\text { Workplace - generator } 7^{\text {th }} \text { block } \\
\text { In front of powering exciter system }\end{array}$} \\
\hline 183 & - & - & medium & $\checkmark$ \\
\hline \multicolumn{5}{|c|}{ Rim Lines under generator $7^{\text {th }}$ block } \\
\hline 335 & - & - & medium & $\checkmark$ \\
\hline \multicolumn{5}{|c|}{ Workplace at generator $-8^{\text {th }}$ block } \\
\hline 447 & - & - & medium & $\checkmark$ \\
\hline \multicolumn{5}{|c|}{ Workplace at measuring instruments } \\
\hline 36.40 & - & - & low & - \\
\hline \multicolumn{5}{|c|}{ Workplace at Cooling system } \\
\hline 181 & & & medium & $\checkmark$ \\
\hline
\end{tabular}

Note: Reference level - $100 \mu \mathrm{T}$

As it could be seen on the transformer platform, the low ALs for the electric field strength for non-thermal effects are exceeded. The electric field strengths exceed reference levels according to CR 1999/519/EC [1] on workplaces around block transformers and transformer platform. No values above the ALs for magnetic flux density were registered but, at several points, values exceeding of the reference levels according to CR 1999/519/EC [1] were registered.

\subsection{Electrolysis facility}

The main source of a permanent magnetic field is the DC power supply to the electrolysis facility. In this case, the electrolyzer is completely shielded.

A conservative estimate of the exposure was made on the basis of averaged field values for two different distances from the facility $-0.1 \mathrm{~m}$ and $0.5 \mathrm{~m}$, at two heights to the floor of the room - at the worker's head $(1.8 \mathrm{~m})$ and the chest $(1.5 \mathrm{~m})$.

The assessment takes into account the fact that there is no permanent workplace in the room. The measured values in the electrolysis facility at the electrolyzer are in the range of 0.06 to $0.79 \mathrm{mT}$. Magnetic field density values of the static field exceeding $0.5 \mathrm{mT}$, which is the AL for interference with active implanted devices, e.g. cardiac pacemakers, are recorded in single points adjacent to the supply cables (at $0.1 \mathrm{~m}$ ) and at the entrance to electrolyzer.

\subsection{Workshops with metalworking machines:}

\section{lathes, milling machines, electric welding}

The sources of EMF in this workshop are the following: power tools of metalworking machines; power supply to the plasma system; the arc welding power generator; cables with high values of the electrical current at arc welding.

At the considered work places, the measured EMF values were as follows:

- $\quad$ Extremely low frequency (ELF) electric field strength from 1.45 to $2.65 \mathrm{~V} / \mathrm{m}$.
- Magnetic flux density (magnetic induction) in the ELF) range: $0.08 \mu \mathrm{T}$ to $23.5 \mu \mathrm{T}$.

\section{CONCLUSION}

The measured values of electric field strengths and magnetic flux density in the ELF range (mainly power frequency $50 \mathrm{~Hz}$ ) do not exceed the action values for non-thermal effects, except for single points on a transformer platform where the low action values are exceeded for the electric field strength. At the same points, values above the reference, in accordance with CR 1999/519/EC, are also established for both the electric field strengths and magnetic flux density.

Notwithstanding the single values exceeding the low ALs, the results show that the exposure limit values (ELVs) with respect to the health effects are met. A health risk associated with exposure to electromagnetic fields at the described workplaces cannot be expected for workers at a specific risk because the exposure limit values are not exceeded.

There is a health risk for workers at specific risk (carrying active and passive implants, medical devices on their body (pumps) and pregnant women working on or in the immediate vicinity of the transformer site, as well as at individual points in the electrolysis facility.

In the light of the results of the study and the established health risk to workers', recommendations have been made to the employer, which are related to working practices for minimizing exposure, safety rules and practices, warning signs, training of workers and health surveillance.

On the workplaces for plasma cutting, arc and oxygene welding workers are expected to be exposed to other part of non-ionizing radiation - optical radiation, which is the subject of a separate assessment in the present study.

\section{REFERENCES}

1. The Council of European Union. (Jul. 12, 1999). Council Recommendation 1999/519/EC on the limitation of exposure of the general public to electromagnetic fields (o Hz to $300 \mathrm{GHz}$ ).

Retrieved from:

https://eur-lex.europa.eu/legal-

content/EN/ALL/?uri=CELEX\%3A31999Ho519

Retrieved on: Nov. 15, 2019

2. The European Parliament and the Council of European Union. (Jun. 26, 2013). Directive 2013/35/EU on the minimum health and safety requirements regarding the exposure of workers to the risks arising from physical agents (electromagnetic fields) (2oth individual Directive within the meaning of Article 16(1) of Directive 89/391/EEC) and repealing Directive 2004/40/EC.

Retrieved from:

https://eur-lex.europa.eu/legalcontent/EN/TXT/?uri=celex\%3A32013Lo035 Retrieved on: Jan. 12, 2020

3. M. Israel, M. Ivanova, V. Zaryabova, T. Shalamanova, P. Ivanova, "Occupational exposure to electromagnetic field - transposition of the European policy," in Proc. $6^{\text {th }}$ Int. Conf. Radiation and Applications in Various Fields of Research (RAD 2018), Ohrid, Macedonia, 2018, pp. $197-201$.

DOI: 10.21175/radproc.2018.42 
M. Israel et al., EMF exposure and risk assessment of electricity workers, RAP Conf. Proc., vol. 5, 2020, 51-54

4. Electromagnetic fields, vol. 1, Non-binding guide to good practice for implementing Directive 2013/35/EU, European Commission, Luxembourg, Luxembourg, 2016.

Retrieved from:

http://bookshop.europa.eu/en/non-binding-guide-togood-practice-for-implementing-directive-2013-35-euelectromagnetic-fields-pbKE0415140/

Retrieved on: Jan. 20, 2020

5. Electromagnetic fields, vol. 2, Non-binding guide to good practice for implementing Directive 2013/35/EU, European Commission, Luxembourg, Luxembourg, 2016.

Retrieved from:

http://bookshop.europa.eu/en/non-binding-guide-togood-practice-for-implementing-directive-2013-35-euelectromagnetic-fields-pbKE0415141/

Retrieved on: Jan. 20, 2020

6. Electromagnetic fields, Guide for SMEs, Non-binding guide to good practice for implementing Directive 2013/35/EU, European Commission, Luxembourg, Luxembourg, 2015.

Retrieved from: http://bookshop.europa.eu/en/non-binding-guide-togood-practice-for-implementing-directive-2013-35-euelectromagnetic-fields-pbKE0415142

Retrieved on: Jan. 20, 2020

7. Министерство на труда и социалната политика и Министерство на здравеопазването на България. (Ноември 15, 2016). Бр. РД-о7-5. Наредба за минималните изисквания за осигуряване на здравето и безопасността на работещите при рискове, свързани с експозиция на електромагнитни полета.

(Ministry of labor and Social Policy and Ministry of Health of Bulgaria. (Nov. 15, 2016). No. RD-O7-5. Ordinance for the minimal requirements for providing health and safety at work at risks by exposure to electromagnetic fields).

Retrieved from:

https://dv.parliament.bg/DVWeb/fileUploadShowing.j sp?\&idFileAtt $=245316 \&$ allowCache $=$ true\&openDirectly =false

Retrieved on: Jun. 10, 2019 